\title{
Analysis of Potential Export Diversification of Rubber Tire Derivative Products to 9 Nontraditional Countries
}

\author{
Aulia Niky Pinandhita \\ Staff at Section of Production Statistics \\ Statistics of Kapuas Regency \\ Central Kalimantan, Indonesia \\ aulia.niky@bps.go.id
}

\author{
Neli Agustina \\ Secretary at Reasearch Center and Community Service \\ STIS Polytechnic Statistics \\ East Jakarta, Indonesia \\ neli@stis.ac.id
}

\begin{abstract}
Indonesia economic resilience is in a vulnerable condition amid the high global economic challenges. For this reason, there is a need for a strategy to improve the economy sustainably, one of which is through increasing and stabilizing exports. However, so far the Indonesian export market has only been concentrated in the main destination countries (traditional countries) such as the United States, Japan and the European Union, which causes export performance to be unstable due to the economic shocks experienced by these destination countries. This happened in rubber tire products, from 2001-2016 exports increased but tended to be unstable. So that, to increase and stabilize rubber tire exports, we can do market expansion (diversification) to potentially nontraditional countries (besides the main export destination countries). The study aims to identify nontraditional countries that have the potential to diversify the export market of rubber tire derivative products using the Export Product Dynamic (EPD) analysis and analyze the variables that affect rubber tire exports to nontraditional countries in 2001 2016 using panel data regression. The results showed that potential nontraditional countries for the diversification of the car tire export market were Brazil, the Philippines, Canada, Mexico and Egypt, for bus and lorry tire were the Philippines and Mexico, while bicycle tires were the Philippines and Egypt. Variable real GDP per capita, export prices of rubber tires and economic distance affect the export volume of rubber tires. While the real exchange rate and the export volume of rubber tires apart from Indonesia have no effect.
\end{abstract}

Keywords- export diversification, rubber tire derivative products, nontraditional market, EPD, panel data regression

\section{INTRODUCTION}

\section{A. Background}

Trade can be an incentive in the development process continuity and in the creation of rapid economic growth [5]. According to [13] export is one of the parameter that can describe the economic condition of a country. However, for the past few years, its contribution for Gross Domestic Product (GDP) has decreased and its growth tends to fluctuate [16]. One of the regulations issued by the Ministry of Trade to increase the export performance is the diversification of market and export product [6]. Diversification is needed because the export that is concentrated in one market or certainty product is prone to external turmoil [7]. The market diversification is intended to widen Indonesia's trade share in nontraditional countries, which include countries that have not done trade intensively with Indonesia (beside United States of America, European Union, Japan, China, India, Singapore, Malaysia, South Korea, Thailand, and Taiwan), in which their markets are apparently have potential to be developed [9]. Meanwhile, the diversification of export product is done by changing the primary export product with processed good that have higher added-value. Margins, column widths, line spacing, and type styles are built-in; examples of the type styles are provided throughout this document and are identified in italic type, within parentheses, following the example. Some components, such as multi-leveled equations, graphics, and tables are not prescribed, although the various table text styles are provided. The formatter will need to create these components, incorporating the applicable criteria that follow.

Indonesia's export is dominated by natural recourses and their processed products. This is supported by the abundant of natural recourses in Indonesia, which include natural rubber. In 2014, Indonesia became the second biggest natural rubber producer after Thailand [10]. The market share of natural rubber is dominated by foreign market, but the weakening economy of export destination countries caused by the global financial crisis is causing the decrease of export and the increase of domestic stock. Because of that, there is a need for a downstream process in order to maintain the absorption of natural rubber [15]. Rubber tire is one of the processed products of natural rubber that has a high addedvalue. The market potential of rubber tire is increasing concomitantly with the development of automobile industry and the rapid mobility of the people. Almost 70 percent of rubber tire production in Indonesia is exported overseas. However, from 2011 (Fig.1) the gap between rubber tire export to traditional countries and nontraditional countries is increasing, which shows the increase of concentration of rubber tire export to traditional market. 


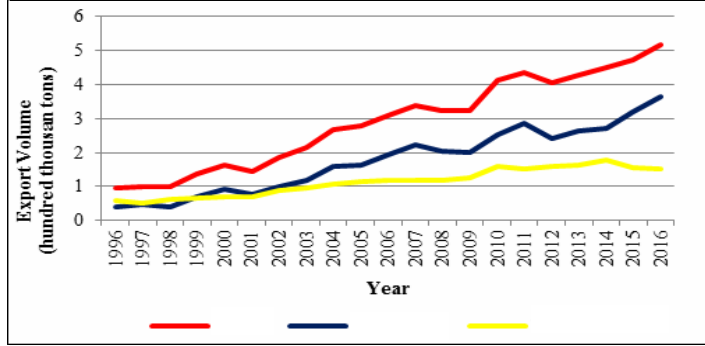

Fig. 1. Volume of rubber tyre export from Indonesia to world, traditional market and nontraditional market in 1996-2016 (hundreds thousands of tons)

Because of that, the performance of Indonesia's rubber tire export is totally dependent to the traditional market. This can be seen on 2008, 2009, and 2012, in which the decrease of rubber tire export caused by financial crisis in United States and Europe (traditional market). Therefore, export diversification of rubber tire export to potential nontraditional market is needed in order to maintain and increase the performance of rubber tire export.

Based on the explanation above, the aim of this study is to research the potency of export diversification for the derivative product of rubber tire as well as to study the variable that effect the export of rubber tire to nontraditional country from 2001 until 2016.

\section{B. Literature Review}

Related research done by $\mathrm{Li}$ [4] shows that the higher the economic scale is the higher export and import component and manufacture goods will be. This economic scale is shown by the average GDP real of China and its trading partner. FDI has a positive effect on the export and import component manufacture. While the economic gap has a negative effect on the export and import of both component as well as end product manufacture. Rinaldi [14] studies the analysis of competitiveness and other factors that affect the trade flow of superior commodity export of Indonesia to South Africa which shows that on the manufacture sector, GDP real South Africa and rupiah exchange rate have a positive impact while the export price and nontariff measures (NTM) have a negative impact. Sunardi [2] finds that rubber tire is a superior commodity for export. The result of regression shows that GDP per capita of OKI countries has a positive impact on the export of soup and rubber tire, while also has a negative impact on the export of palm oil and fatty acid. The variable differentiation GDP per capita between Indonesia and OKI countries has a negative impact on soup export. Rupiah exchange rate only impacts the export of rubber tire with positive mark. The economic gap and tariff have a negative impact on the export of palm oil and fatty acid, while the share of language has a positive impact on the export of rubber band and paper.

\section{METHODOLOGY}

The data used is secondary data from 9 nontraditional export destination countries of Indonesia's rubber tire that has annual increase of export average which include Australia, Brazil, Canada, Egypt, Jordan, Mexico, New Zealand, Philippine and Sri Lanka. The derivative product of rubber tire is limited to three types that have the biggest proportion on Indonesia's rubber tire export, which include (1) car tires, (2) bus or truck tires, and (3) bicycle tires. To know the nontraditional countries that have potential as market diversification for derivative product of rubber tired, Export Product Dynamic (EPD) is used.

EPD is an indicator that rates the position of a country's market to certain product for a certain export destination market [8]. This position is seen from the combination of market share (the growth of total export market share of a country in the destination country) and the dynamic product (the growth of certain product's export market share of a country in the destination country) that produce four positions which include rising star, falling star, lost opportunity, and retreat. The EPD matrix (axis$\mathrm{x}$,axis-y) is obtained from the calculation of the following formula:

$$
\begin{aligned}
& y-\text { axis }=\frac{\left(\sum_{t=1}^{t}\left(\frac{X_{i j}}{W_{i j}}\right)_{t} x 100 \%-\sum_{t=1}^{t}\left(\frac{X_{i j}}{W_{i j}}\right)_{t-1} x 100 \%\right)}{T} \\
& x-\text { axis }=\frac{\left(\sum_{t=1}^{t}\left(\frac{X_{i j}}{W_{i}}\right)_{t} x 100 \%-\sum_{t=1}^{t}\left(\frac{X_{i}}{W_{i}}\right)_{t-1} x 100 \%\right)}{T}
\end{aligned}
$$

Explanation:

$$
\begin{aligned}
& \mathrm{X}_{\mathrm{i}}=\text { total export value from Indonesia to } \\
& =\text { nontraditional country }(1,2, \ldots 9) \\
& =\text { derivative product of rubber tire }(1,2,3) \mathrm{t}=
\end{aligned}
$$

Panel data regression analysis is used to know the variables that effect Indonesia's rubber tire export to nontraditional country. The variables used in this research are as follow:

1) Volume of Indonesia rubber tire export to nine nontraditional countries as dependent variable from United Nation (UN) Comtrade in thousand tons.

2) Real GDP per capita of the nine nontraditional countries from Worldbank in thousand dollars per capita.

3) The price of rubber tire export (thousand dollars/ton), obtained from rubber tire export value ratio to each nontraditional countries with its volume.

4) The real exchange rate (in US dollar per nontraditional country currency). Obtained from multiplying the nominal exchange rate (US dollar per nontraditional country currency) with the ratio of nontraditional countries' consumer price index and United State' consumer price index. The data source from International Monetary Funds (IMF))

5) The economic distance (thousand $\mathrm{km}$ ) show economic similarity between one country and another [12]. 
Obtained from multiplaying the geographic distance between Indonesia and nontraditional countries (from CEPII) by the Real GPD per capita ratio of nontraditional country and Indonesia.

6) Export volume of rubber tire to nontraditional countries beside from Indonesia in thousand tons (caculated based on UN Comtrade data).

From the variables above, the model of data regression panel is as follow:

$$
\begin{aligned}
V O L_{i t}= & \alpha+\beta_{1} \text { GDPRIILP }_{\mathrm{it}}+\beta_{2} X \text { PRICE }_{\mathrm{it}}+\beta_{3} R E R_{\mathrm{it}} \\
& +\beta_{4} \text { ECODIST }_{\mathrm{it}}+\beta_{5} \text { VOLRW }_{\mathrm{it}}+\varepsilon_{\mathrm{it}}
\end{aligned}
$$

\begin{tabular}{|c|c|}
\hline $\mathrm{OL}_{\text {it }}$ & $\begin{array}{l}=\text { volume of rubber tire export from } \\
\text { Indonesia to nontraditional country-i on } \\
\text { year- } \mathrm{t}\end{array}$ \\
\hline DPRIILP $_{\text {it }}$ & $\begin{aligned}= & \text { real GDP per capita of nontraditional } \\
& \text { country- } \mathrm{i} \text { on the year- } \mathrm{t}\end{aligned}$ \\
\hline XPRICE $_{\text {it }}$ & $\begin{aligned} &= \text { price of rubber tire export from Indonesia } \\
& \text { in nontraditional country-i on year- } \mathrm{t}\end{aligned}$ \\
\hline $\mathrm{RER}_{\mathrm{it}}$ & $\begin{aligned}= & \text { real exchange rate of nontraditional } \\
& \text { country- } \mathrm{i} \text { on year- } \mathrm{t}\end{aligned}$ \\
\hline CODIST $_{\text {it }}$ & $\begin{aligned}= & \text { economic distance between Indonesia and } \\
& \text { nontraditional country-i on year- } \mathrm{t}\end{aligned}$ \\
\hline VOLRW $_{\text {it }}$ & $\begin{aligned}= & \text { volume of rubber tire export to } \\
& \text { nontraditional country-i beside from } \\
& \text { Indonesia on year- } \mathrm{t}\end{aligned}$ \\
\hline $\mathrm{k}$ & $=$ independent variable $(1,2, \ldots, 5)$ \\
\hline & cy $(1,2, \ldots, 9)$ \\
\hline & search period $(2001, \ldots, 2016)$ \\
\hline
\end{tabular}

Explanation:

\section{RESULT AND DISCUSSION}

\section{A. General Description of Rubber Tire Export to} Traditional Country and Ninen Nontraditional Country

Rubber tire is one of Indonesia export commodity, in 2016 Indonesia placed 13th as rubber tire exporter even with the low market share which only reach 2.09 percent. The high rate of rubber tire production is reinforced by the abundance of natural rubber which is an important component in the rubber tire production. Some tire industries in Indonesia include Gajah Tunggal, Goodyear, Bridgestone, and Multi Strada [6].

Fig. 2 shows the development of rubber tire export to traditional country as well as the nine nontraditional countries from 2001-2016. The volume of rubber tire export to traditional market is higher than to the nine nontraditional countries. The average volume of export to the nine nontraditional countries reaches 255 thousand tons with the share reaching 63 percent from the total of rubber tire export. Moreover, the export volume also tends to increase with the average escalation of 11.57 percent per year.

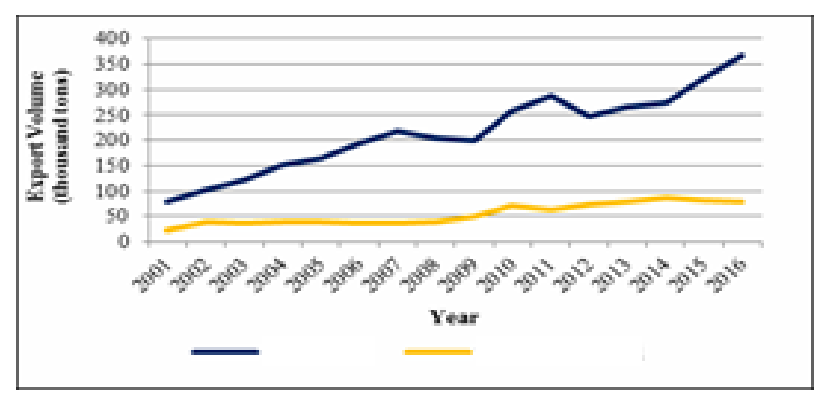

Fig. 2. Volume of rubber tyre export from Indonesia to traditional market and 9 nontraditional market in 2001-2016 (thousand tons)

These two things show that concentration of rubber tire export to traditional country is quite high. The volume of rubber tire export to the nine nontraditional countries has average of 56 thousand tons per year with the share reaching 15.66 percent from Indonesia rubber tire export to the world. The main country that become export destination of Indonesia's rubber tire are Philippine, Australia, and Egypt. On the years of crisis, it is found that the export to the nine nontraditional countries do not face any decrease even though these countries are also impacted by the crisis, especially the global financial crisis on 2008-2009. This shows that Indonesia's rubber tire export to the nine nontraditional countries has potential for development, because Indonesia export share against the nine countries is still low, which is only 0.74 percent.

In order for the utilization of this potential can be right on target, it is important to elaborate the rubber tire according to its derivative product or type. There are 14 derivative products of rubber tire according to its usage. Rubber tire product that becomes the superior export in 2001-2016 is rubber tire for car (HS 401110), followed by rubber tire for bus or truck (HS 401120). Then lastly rubber tire for bicycle (HS 401150)

\section{B. Potency of Export Diversification of Rubber Tire Derivative Product to 9 Nontraditional Countries}

Diversification is one of the Ministry of Trade's regulation [7] that is issued to maintain export stability as well as to increase Indonesia export performance. Diversification of rubber tire product is need because its market share that tends to concentrated to traditional country, while on nontraditional market it has potential to be developed even though the share is still low. Potential marker can be identified using EPD analysis, which is the market or country that is on the raising star position. This position shows the increasing demand of rubber tire derivative product and the increase of Indonesia's market. This indicates that when Indonesia's rubber tire derivative export product is increasing, Indonesia's market share on the nontraditional countries is also becoming more competitive, which mean that Indonesia can compete with other countries that also targeted nontraditional countries as their export destinations.

If Indonesia's market share is strengthened in those countries then the rubber tire derivative product will be easier to market and can increase Indonesia's share. This is what makes the raising star position considered as the most ideal market for the diversification of export market. Meanwhile on the falling star position, the competitive condition of Indonesia's market share is not followed by the 
increase of rubber tire derivative product share. Then, in the lost opportunity position, when the export share of rubber tires derivative product increase, Indonesia's market share is on the condition that is not competitive. The last position is the worse, which is the retreat position, it shows the share of rubber tire derivative product export in nontraditional country is decreasing and tends to stagnant and Indonesia's export market share is also not competitive.

From the result of the EPD calculation for the exported rubber tire derivative products, it is found that for the product of car tires there are five nontraditional countries that have potential to be the destination for export market diversification, which are Brazil, Philippine, Canada, Mexico, and Egypt (Fig. 3). Then, for the derivative product of bus and truck tires, the countries that have potential position are Philippine and Mexico (Fig.4). Meanwhile for the derivative product of bicycle tires, the potential countries are Philippine and Egypt (Fig. 5).

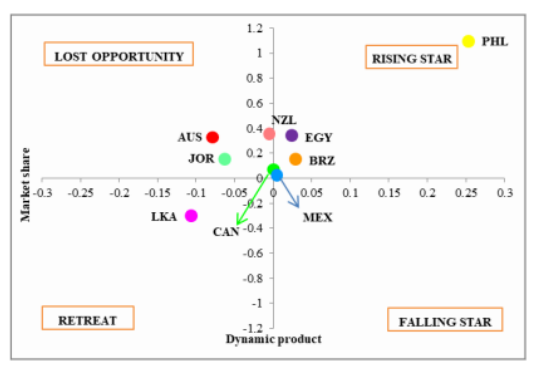

Fig. 3. EPD matrix for new pneumatic tyres of rubber, ued on cars

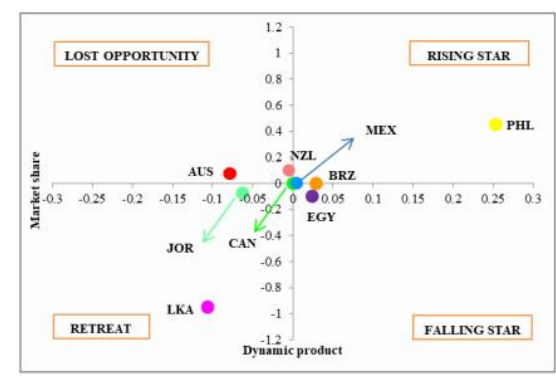

Fig. 4. EPD matrix for new pneumatic tyres of rubber, used on cars

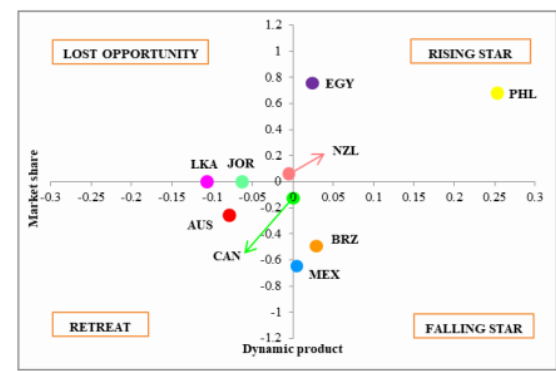

Fig. 5. EPD matrix for new pneumatic tyres of rubber, ued on cars

\section{Variables that Affect the Export of Rubber Tire to 9} Nontraditional Countries on 2001-2016

The best model for panel data regression can be found after running the data with several tests. The first test is the Chow test to detect the presence or absence of individual effects in the model, so that it can be known whether Common Effect Model (CEM) or Fixed Effect Model (FEM) is the best. From the test results obtained $\mathrm{F}=48.16$ is greater than $\mathrm{F}(0.05 ; 8 ; 130)=2.01$ so that with a 5 percent significance level it can be concluded that there are individual effects or FEM is better than CEM. Because the FEM is selected, the test is continued with the Hausman test, the results of $\chi 2=47.21$ are greater than $\chi 2(0.05 ; 5)=11.07$ so that with a 5 percent significance level it can be concluded that there is a correlation between individual effects and independent variables so that FEM is better than Random Effect Model (REM). The next step is testing the structure of residual variance covariance to determine the appropriate estimation method for the selected model (FEM). The result are $\mathrm{LM}$-value $=71.07$ is greater than $\chi 2(0.05 ; 8)=15.51$ and the value of $\lambda$-LM $=72.04$ is greater than $\chi 2(0.05 ; 36)=$ 50.99 so that with a 5 percent significance level it can be concluded that there are heteroscedasticity and crosssectional correlation in the residual covariance variance of the selected model. So the right estimation method for FEM is Seemingly Unrelated Regression (SUR). After that, the classic assumption test is performed on the residual selected model (FEM-SUR). Because the problem of heteroscedasticity and autocorrelation has been overcome by the model and estimation selected method, the classical assumption test that is carried out is only normality and non-

multicollinearity. Based on the results of the normality test the JB value of 1.48 is smaller than $\chi 2(0.05 ; 36)=5.99$ so it can be concluded that the assumption of normality is fulfilled. The independent variable VIF is less than 10, so the assumption of nonmulticolinierity is also fulfilled.

TABLE I. ESTIMATION RESULT

\begin{tabular}{|c|c|c|c|}
\hline \multirow{2}{*}{ Variable } & \multicolumn{3}{|c|}{ Estimated Model } \\
\cline { 2 - 4 } & Coefficient & $\boldsymbol{t}$ & Prob(t) \\
\hline $\mathrm{C}$ & -20.6211 & -9.3673 & 0.000 *** $^{*}$ \\
\hline GDPRIILP & 1.3101 & 1.4808 & $0.0000 * * *$ \\
\hline XPRICE & 0.4041 & 2.4420 & $0.0160 * *$ \\
\hline RER & 0.6955 & 0.9032 & 0.3681 \\
\hline ECODIST & 0.0236 & 3.0975 & $0.0024 * *$ \\
\hline VOLRW & -0.0001 & 0.2605 & 0.7950 \\
\hline $\mathrm{R}^{2}{ }_{\text {adj }}=0.8759$ & \multicolumn{2}{|c|}{ Prob(F) $=0.000 * * *$} \\
$(* *)$ significance level at $1 \% ;(* *)$
\end{tabular}

The estimated equation that is formed is as follow:

$$
\begin{aligned}
\widehat{V O L}_{i t}= & -20.6211+\hat{\mu}_{i}+1.3101 \text { GDPRIILP }_{i t}{ }^{* 8 *} \\
& +0.4041 \text { XPRICE }_{i t}{ }^{* 8}+0.6955 \text { RER }_{i t} \\
& +0.024 \text { CCODIST }_{i t}{ }^{* 8}-0.0001 \text { VOLRW }_{i t}
\end{aligned}
$$

The simultaneous test one the model shows significant result so it can be concluded there is at least one independent variable in the model that volume of rubber tire export from Indonesia to nine nontraditional countries. Besides that, the independent variables that used in this study are able to explain 87.6 percent variation in the volume of rubber tire export from Indonesia to nine nontraditional countries, while 12.7 percent was explained by other variables not included in the model. The independent variables that are statistically have significant effect are real GDP per capita, rubber tire export price and economic distance.

Real GDP per capita of the nine nontraditional countries is significant and has positive relation to the volume of Indonesia's rubber tire export, this shows that every 
increase of real GDP per capita in the amount of 1 US dollar per population will increase the volume of Indonesia's rubber tire export to the nine nontraditional countries as much as 1.3101 tons, with the other variables considered constant. This result is corresponding with the research done by Sunardi [2] especially in the result analysis on rubber tire commodity, real GDP per capita shows the average population income of a certain country, the higher their income the higher their purchasing power are, which resulted in the increase of demand for goods and services which then will increase the export to that country. The positive impact from real GDP per capita shows that rubber tire is normal good.

The next variable is price which has a positive relation with export volume of Indonesian rubber tires to nine nontraditional countries. Every 1 US dollar increase in the price of Indonesian rubber tire export, the volume of Indonesian rubber tire export to nine nontraditional countries will increase by 0.4041 tons. This is not accordance with the Rinaldi [13] result which state that an increase in the price of goods/services will reduce the demand for these goods/services. However, based on real exchange rate data, during 2001-2016 there tends to be an appreciation of nontraditional countries currencies per US dollar, so that high rubber tire export prices in US dollar, can still be accessed by nontraditional countries because of their currencies strengthened against the US dollar.

Next, the real exchange rate variable (US dollar per nontraditional country's currency) shows positive relation that is not significant. Despite it shows no statistically effect, but economically that relation is already corresponding, because when there is an increase of real exchange rate or appreciation of nontraditional country's currency against US dollar then the price of goods in the nontraditional country will be relatively higher than in other countries, which result, demand for import goods in the nontraditional country increase, in which resulted the increase of export volume in exporter country.

The economic distance represents the gap between Indonesia and the nine nontraditional countries which is seen from the economic aspect; the closer the distance, the more similar is the economy of Indonesia and the nine nontraditional countries. The estimation result shows that economic distance is significant and its relation is positive with the volume of Indonesia's rubber tire export to the nine nontraditional countries. So that when the economic distance between Indonesia and the nine nontraditional countries is increased $1 \mathrm{~km}$ then the volume of Indonesia's rubber tire export will increase for 0.024 ton. This positive relation indicates that the nontraditional country that does not have similar economy with Indonesia is a potential export market. This is suspected as the result of the abundance ownership of production factor of rubber tire in Indonesia like natural rubber, which enable Indonesia to produce rubber tire more efficiently, in which resulted in the competitiveness of its price [3].

The next variable is the volume of rubber tire export to the nine nontraditional countries beside from Indonesia which shows negative relation to the volume of rubber tire export even though it is not significant. Although statistically this variable does not have any effect against the volume of Indonesia's rubber tire export, but economically when the volume of foreign export is increasing, Indonesia's market share of rubber tire in those countries will decrease, which resulted in the decrease of Indonesia's rubber tire export volume.

\section{CONCLUSION}

According to the explanation above, it can be concluded that Indonesia's rubber tire export to the nine nontraditional countries' markets can still be improved, because Indonesia's market share against the world export to those nine countries is still low. For the regulation of uplifting export can be right on the target, it is important to study which nontraditional countries that have potency to be the export destination for Indonesia's rubber tire derivative product. According to the result of the EPD calculation, it is known that for car tires export, the potential nontraditional countries are Brazil, Philippine, Canada, Mexico, and Egypt. While for bus and lorry tires, the potential countries are Philippine and Mexico, then for bicycle tires the potential countries are Philippine and Egypt. From the result of data panel regression analysis shows real GDP per capita, tire export price and economic distance have statistically positive impact on volume of Indonesian tire export to nine nontraditional countries. Meanwhile real exchange rate which also has positive marked and volume of tire export besides from Indonesia which has negative marked are not statistically significant to the volume of Indonesian tire export to nine nontraditional countries.

\section{REFERENCES}

[1] Centre d'Etudes Prospectives et d'Informations Internationale (CEPII). http://www.cepii.fr/CEPII/en/bdd_modele/bdd_modele.asp.

[2] D. Sunardi, Analysis of Competitiveness and Determinant Factor of Indonesia's Leading Comodities Export to Organization of Islamic Cooperation [Thesis], Bogor: Bogor Aglicultural Institute, 2015.

[3] F. Amir, The Impact of Horizontal and Vertical Export Diversification on Economic Growth od ASEAN Member Countries, Bogor: Bogor Aglicultural Institute, 2016.

[4] K. Li, L. Song, and X. Zhao, "Component trade and China's global economic integration, Research Paper No. 2008/101 UNU-WIDER.

[5] M.P. Todaro and S.C. Smith, Economic Development in the Third World, 1st chapter, Transl. H. Munandar, English, Jakarta: Erlangga, 2003.

[6] Ministry of Industry of Republic of Indonesia. Industrial Company Directory, http://www.kemenperin.go.id/direktoriperusahaan? what $=$ Ban $+\&$ prov $=0$. Ministry of Trade of the Republic of Indonesia.

[7] Ministry of Trade of the Republic of Indonesia. Minister of Trade Regulation Number 81/M- DAG/PER/11/2016. Jakara: Jakarta: Ministry of Trade. 2016

[8] Ministry of Trade of the Republic of Indonesia, "Policy studies on the development of market and product export diversification", Jakarta: Ministry of Trade, 2011.

[9] Ministry of Trade of the Republic of Indonesia, "Study of development potential of diversification export to nontraditional market", Jakarta: Ministry of Trade, 2013.

[10] Indonesia-investment, Rubber (Natural), https://www.indonesiainvestments.com/id/bisnis/komoditas/karet/item 185 .

[11] International Monetary Fund (IMF). International Financial Statistics. http://data.imf.org

[12] P. Ghemawat, "Distance still matters, the hard reality of global expansion", Harvard Business Review, 2011.

[13] R. Oktaviani and T. Novtanti, International Trade Theory: Its Application in Indonesia, Bogor: Bogor Aglicultural Institute, 2014. 
[14] R. Rinaldi, Analysis of Competitiveness and Factors Affecting Trade Flow of Indonesia's Leading Comodities Export to South Africa [Thesis]. Bogor: Bogor Aglicultural Institute, 2014.

[15] S. Deny, (11 February 2018). 70 Percent of Indonesia Tire Production is Exported to Other Countries, Liputan6 https://www.liputan6.com/bisnis/read/3276705/70-persen-produksiban-ri-diekspor- ke-negara-lain.
[16] Statistics Indonesia, Export and Import Value (million US\$) 1975 2016, https://www.bps.go.id/statictable/2014/09/08/1002/nilaiekspordan-impor-juta-us-1975-2016.html.

[17] United Nation Commodity Trade (UN Comtrade). https://comtrade.un.org/data/

[18] World Bank Data. https://data.worldbank.org/. 